\title{
SOME WESTERN CANADIAN BAT RECORDS
}

DAVID B. SCHOWALTER, Alberta Fish \& Wildlife Division, 6909 - 116 Street, Edmonton, Alberta T6H 4P2 and WM. J. DORWARD, Animal Pathology Division, Agriculture Canada, 3802 West 4 th Avenue, Vancouver, B.C. V6R 1P5

Considerable numbers of bats from western Canada are submitted annually for rabies diagnosis to the Animal Diseases Research Institute (Western) at Lethbridge. Since 1973 most of these bats have been identified. In 1972 a bat research program was initiated by the Alberta Department of Agriculture and the Fish and Wildlife Division of the Alberta Department of Lands and Forests (now Recreation, Parks and Wildlife). Discussed here are occurrences of interest in determining distribution $O F$ bat species which have been discovered in the course of these activities. Specimens of unusual interest were placed in the Provincial Museum of Alberta or the National Museum of Natural Sciences.

\section{Species Accounts}

LONG-EARED MYOTIS - The only published record of Myotis evotis from the plains of Alberta is of a specimen taken $9.6 \mathrm{~km}$ west of Rumsey. ${ }^{1}{ }^{8} \mathrm{We}$ have captured 31 long-eared myotis at this location where it appears to be the most abundant bat species. As well a maternity colony of 10 to 15 adults, known to have been active since before 1972, is located in an attic in the hamlet of Hesketh. The attic is unheated and better ventilated than those colonized by little brown and big brown bats with which we are fimiliar. These occurrences and those from imilar areas of Saskatchewan suggest that this species is likely a wide spread esident of arid river valleys of outhern Alberta and Saskatchewan. ${ }^{36}$

LONG-LECGED BAT - In Alberta Myotis volans is recorded from Henry House and Dried Meat Lake.' ${ }^{8}$ Soper predicted the occurrence of the pecies in the Milk River Valley. ${ }^{8}$ We now have an adult male and an adult female netted July 4, 1976 under a yard light near the Milk River immediately east of Writing-on-Stone Provincial Park. The female was not pregnant or lactating.

SMALL-FOOTED BAT - Alberta records of Myotis leibii are from the Red Deer River near Rumsey, Munson and Jenner; and the Milk River $25.6 \mathrm{~km}$ west of Wildhorse. ${ }^{2}{ }^{8}$ We have 11 captures at the Rumsey location, as well as captures in Dinosaur Provincial Park on Sand and Berry Creeks. Specimens are available from Drumheller, Medicine Hat and Lethbridge. As suggested by Jones this bat appears to be widely distributed in southern Alberta. ${ }^{2}$

HOARY BAT - Seventeen Lasiurus cinereus have been submitted for rabies examination from Alberta since 1974, only one of these was an adult male. Although Soper indicates that this species occurs throughout the wooded area of the province records are lacking for much of this area. ${ }^{8}$ Specimens from Grimshaw and Beaverlodge are the first from the Peace River region. In addition hoary bats were collected from Seven Persons, Olds, Willow Creek Provincial Park, Picture Butte, Drumheller, Lethbridge, Skiff, and Rosedale all in the plains region of Alberta.

Nero and Maher report parturition dates of June 24 , and June 25 or 26 , respectively for hoary bats from Saskatchewan. ${ }^{5}$ A female carrying in flight a male and female young was captured during daylight June 1, 1976 in Tisdale, Saskatchewan. The young appeared to be less than a week old.

A slightly earlier birth date is suggested by a specimen taken July 10 , 1975 in Drumheller, Alberta. The 


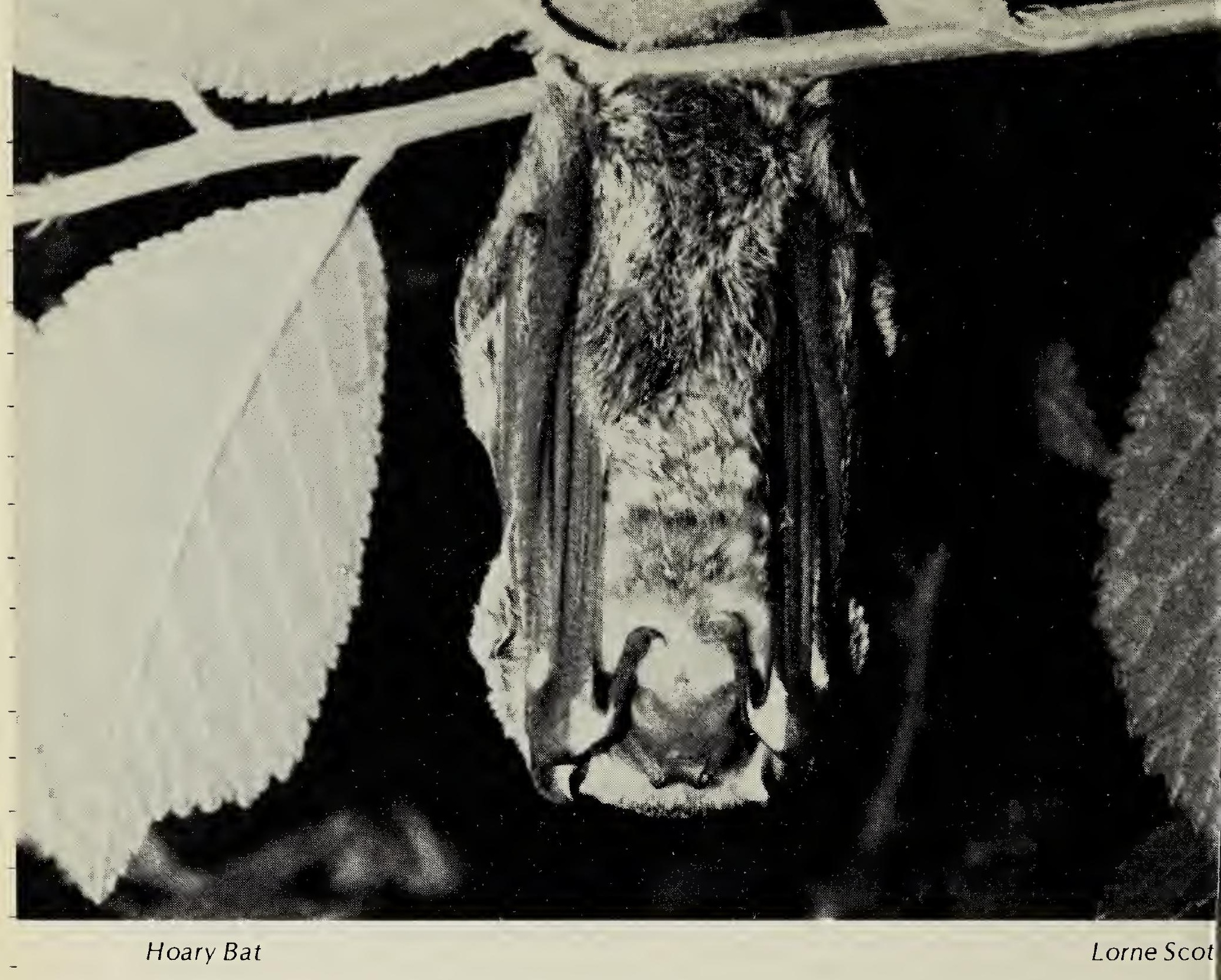

Hoary Bat

gratefully acknowledged.

young bat, which appears sufficiently developed to be volant, was reported to have fallen off the back of a flying animal, thought to be a bat, during daylight.

\section{Acknowledgements}

The work described here was in part funded by the Veterinary Services Division of the Alberta Department of Agriculture. The continued interest and support of Drs. Hugh Vance and G. R. Whenham is greatly appreciated.

Messrs. John Gunson and Lawrence Harder reported early observations of the Myotis evotis colony in Hesketh. Mr. Gunson further provided administrative support for the work described here. Mr. Hugh Smith, of the Provincial Museum of Alberta, and Dr. C. G. van Zyll de Jong, of the National Museum of Natural Sciences, confirmed the identifications of some specimens. The assistance of Messrs. Henry Boumans, Bert Prins, Donald Meyer and Nick Previsich and Ms. Pam Cole in the field and laboratory is
ANDERSON, R. M. 1946. Catalogue o Canadian recent mammals. Nationd Museum of Canada Bulletin 102 Biological Series 31. 238 pp.

${ }^{2} J O N E S, E . \quad T .1974$. Sixteen Alberta ba records, 1971-1974. Blue Jay 32:24 245

${ }^{3}$ MAHER, W. J. 1972a. Two new records c long-eared Myotis in Saskatchewar Blue Jay 30:236.

${ }^{4}$ MAHER, W. J. 1972b. Hoary bat parturitio date and captivity record. Blue Ja 30:236-237

${ }^{5}$ NERO, R. W. 1958. Hoary bat parturitio date. Blue Jay 16:130-131.

${ }^{6}$ NERO, R. W. 1960. Long-eared Myot found in Saskatchewan. Blue Ja 18:181.

${ }^{7}$ NERO, R. W. 1963, A second record of th Long-eared Myotis bat. Blue Ja 21:119.

${ }^{8}$ SOPER, J. D. 1964. The Mammals Alberta. Hamly Press, Edmonto 402pp. 